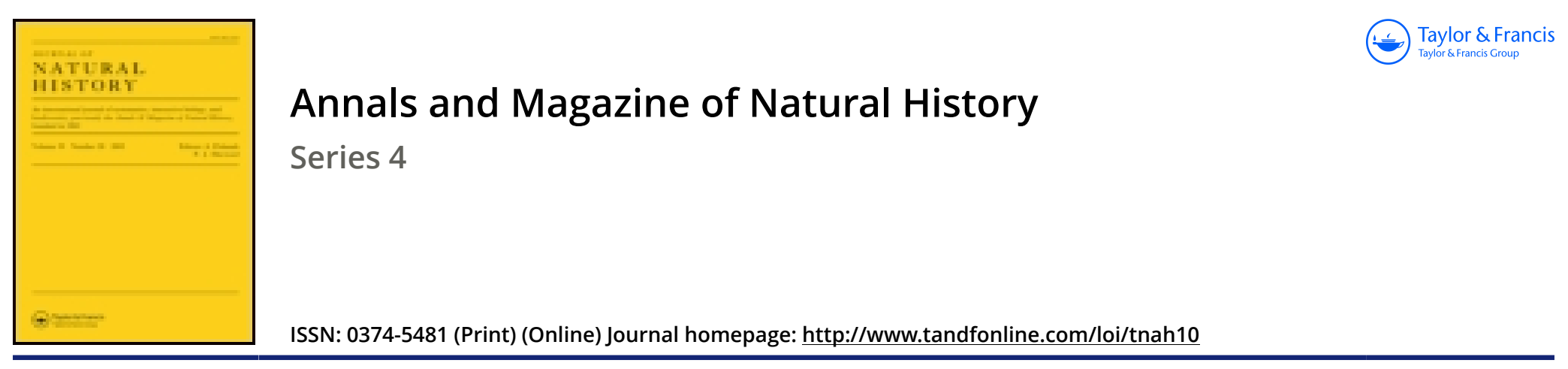

\title{
The late Adrian Hardy Haworth
}

\section{Dr.J.E. Gray F.R.S.}

To cite this article: Dr. J.E. Gray F.R.S. (1871) The late Adrian Hardy Haworth , Annals and Magazine of Natural History, 7:39, 244-245, DOI: 10.1080/00222937108696357

To link to this article: http://dx.doi.org/10.1080/00222937108696357

$$
\text { 曲 Published online: } 19 \text { Oct } 2009 .
$$

Submit your article to this journal $\pi$

LII Article views: 2

Q View related articles 두 
which we heartily concur. In fact we are quite assured that, in the case of a primá facie discovery of a new form, Mr. Watson is too sound a working botanist not to admit that in minute attention to "small differences" and "little distinctions"-occasionally stamped, for attracting or facilitating further observation, and whilst yet unproved to be really trivial or inconstant, with a special name-lies the very safest way to truth in settling the limits ultimately of a species, and this despite all liability to abuse that may accrue in thus "allowing nice opportunities to petty minds to make petty distinctions on paper" (p. 161).

This very valuable portion of the book is followed by a carefully compiled list by Mr. Mitten of all the Mosses and Liverworts (Hepaticce) hitherto discovered in Madeira, the Canaries, and Açores. Of these, we have only time and space to observe that they appear entirely to confirm the conclusion arrived at by Mr. Watson (p. 276) with reference to the Flowering Plants and Ferns, viz. that "on the whole ..... they can hardly be said to yield any special evidence in support of the Darwinian theories;" though instead of admitting that "their affinities on the general view are more in support of those theories than adverse to them," we should rather have remarked that, in many signal and decisive points, they seem to us to run directly counter to them.

Mr. Godman concludes his interesting volume with a short summary and general remarks, followed by a full index of scientific names and two small maps, showing the relative position of the islands and of the whole group. It remains to be noted, for the encouragement of future investigators, that he has still left unexplored in Botany the Lichens, Algæ, and Fungi, and in Zoology the highly interesting provinces, in their relation to the Canaries and Madeira, of the Arachnida, Crustaceans, Radiates, Sponges, Corallines, SeaFishes, and Mollusks.

$\mathrm{He}$ has added, however, to our "helps to knowledge" a book from which not only the practical naturalist, but any one who is at all competent unbiasedly to sift and weigh the alleged "facts" of modern "science," and the varieties of airy theoretic superstructure attempted to be raised upon them, may derive not less profit than interest and entertainment.

\section{MISCELLANEOUS.}

The late Adrian Hardy Hawortm.

By Dr. J. E. GraY, F.R.S. \&c.

IT has often occurred to me that English naturalists have hardly done justice to the great scientific merits of this industrious and far-seeing botanist and entomologist, no doubt in consequence of his being so far in advance of his age at a time when not to be a worshipper of the Jimnean school as understood in England (which is most unlike the practice and example of Linnæus himself) was a sufficient mark of opprobium to almost exclude him from scientific societies. As a 
young man I was very intimate with him, and estimated his labours, but hardly so much as I have been induced to do in later years. He was one of the founders of the Botanic Garden at Hull, where he then resided; but he continued to cultivate plants when he resided at Little Chelsea, and at Church Lane, Old Chelsea ; for he considered it desirable not only to study plants as they were kept in an herbarium, but also to obserre them in a living state, that he might record their mode of growth. When we consider the manner in which he separated the fleshy plants, the Saxifrages, and the bulbous plants into groups, and especially regard the time in which it was done, we are astonished at the accuracy of his observations, which were so unlike the manner in which plants were then studied; and most of his groups are now acknowledged as genera or sections of genera. It was the same with his work on British Lepidoptera: there the various Linnean genera were divided into natural groups, which he fully characterized, all of which are now acknowledged as genera; and he would have been quoted as the author of those genera if he had given them generic names instead of the English or Latin adjective names which he applied to them. We must recollect that this was all original work, published before the writings of Cuvier, Latreille, and other founders of the French school (which was established during the early part of the despotism of the Great Napoleon), whose labours my late predecessor, tutor, and friend, Dr. Leach, first introduced to the knowledge of English naturalists.

On the Adult Form in the Genera Cyprea and Ringicula, and in certain Species of the Genus Astarte. By J. Gwrn JEFERETs, F.R.S.

Mr. Searles Wood, in the last Number of the 'Annals' (p. 172), invited communications on a question propounded by him, viz.:- "If small specimens [of Cyproea europoea and Ringieula auriculata] in the Crag, which have a thickened lip, are not in many instances young shells, what has become of the immature specimens?" I venture to suggest that young shells of both these species, having the usual thin and imperfect lip, will surely be found after further search. I have already given an explanation, in my work on British Conchology (vol. ii. pp. $309 \& 310$, and vol. iv. pp. $402 \& 403$ ) as to the front margin in Astarte and the outer lip in Cyproea, with reference to the age and size of specimens. I lately dredged in the North Atlantic Ringicula auriculata, Menard de la Groye ( $R$. buccinea, Brocchi), $R$. ventricosa, J. Sowerby, and $R$. acuta, Sandberger (the last two species hitherto known as fossil only), all of which in their immature state had a thin and imperfect lip. The young of $C y p r c e a$ europoea is the Bulla diaphana of Montagu.

I may also remark that any young shells "killed for food" would not be necessarily "consumed" or destroyed; so that I have no doubt they will occur in a fossil as well as in a recent state.

25 Devonshire Place, Feb. 15, 1871. 